\title{
Identification of a New Biocontrol Gene in Trichoderma atroviride: The Role of an ABC Transporter Membrane Pump in the Interaction with Different Plant-Pathogenic Fungi
}

\author{
Michelina Ruocco, ${ }^{1}$ Stefania Lanzuise,${ }^{2}$ Francesco Vinale, ${ }^{2}$ Roberta Marra, ${ }^{2}$ David Turrà, ${ }^{2}$ \\ Sheridan Lois Woo, ${ }^{2}$ and Matteo Lorito ${ }^{2}$ \\ ${ }^{1}$ CNR-Istituto per la Protezione delle Piante sez. Portici, Via Università 130, 80055 Portici, Napoli, Italy; ${ }^{2}$ Dipartimento di \\ Arboricoltura, Botanica e Patologia Vegetale (ArBoPaVe), Università di Napoli Federico II, Via Università, 100, 80055 Portici, \\ Napoli, Italy.
}

Submitted 12 June 2008. Accepted 19 November 2008.

\begin{abstract}
Successful biocontrol interactions often require that the beneficial microbes involved are resistant or tolerant to a variety of toxicants, including antibiotics produced by themselves or phytopathogens, plant antimicrobial compounds, and synthetic chemicals or contaminants. The ability of Trichoderma spp., the most widely applied biocontrol fungi, to withstand different chemical stresses, including those associated with mycoparasitism, is well known. In this work, we identified an ATP-binding cassette transporter cell membrane pump as an important component of the above indicated resistance mechanisms that appears to be supported by an extensive and powerful cell detoxification system. The encoding gene, named Taabc2, was cloned from a strain of Trichoderma atroviride and characterized. Its expression was found to be upregulated in the presence of pathogen-secreted metabolites, specific mycotoxins and some fungicides, and in conditions that stimulate the production in Trichoderma spp. of antagonism-related factors (toxins and enzymes). The key role of this gene in antagonism and biocontrol was demonstrated by the characterization of the obtained deletion mutants. They suffered an increased susceptibility to inhibitory compounds either secreted by pathogenic fungi or possibly produced by the biocontrol microbe itself and lost, partially or entirely, the ability to protect tomato plants from Pythium ultimum and Rhizoctonia solani attack.
\end{abstract}

Trichoderma spp. are ubiquitous filamentous fungi known for their ability to colonize a variety of niches, as well as antagonize and control numerous plant-pathogenic fungi. They also have direct beneficial effects on plants, including enhancement of growth, nutrient assimilation, and systemic resistance (Woo et al. 2006; Yedidia et al. 1999, 2000). It has been widely recognized that Trichoderma spp. use multiple mechanisms and different modes of action when they interact with plant

This paper is dedicated to the memory of Giovanni Del Sorbo.

Nucleotide sequence data for gene $T a a b c 2$ is available in the GenBank database under accession number AY911669.

Corresponding author: M. Lorito; E-mail: lorito@unina.it; Telephone: (+39) 0812539376; and other microbes (Brunner et al. 2005; Harman et al. 2004a; Sivasithamparam and Ghisalberti 1998; Woo et al. 1999).

The antimicrobial and mycoparasitic activities of Trichoderma spp. biocontrol strains have been investigated in depth, also by using functional genomics techniques (Lu et al. 2004; Marra et al. 2006; Rey et al. 2004), and several "virulence" factors capable of killing the host fungus have been identified (Benítez et al. 2004; Daniel and Filho 2007; Liu and Yang 2007; Lorito et al. 1994; Sharon et al. 2001; Vinale et al. 2006; Wilhite et al. 2001). In addition, the ability of these fungi to grow well in a medium amended with plant-pathogen-derived (i.e., Botrytis cinerea, Rhizoctonia solani, or Fusarium oxysporum) secondary metabolites or mycotoxins is a common finding. However, the mechanisms by which Trichoderma spp. protect themselves from the host and their own toxins are still unknown. The only molecule for which a protective role has been proposed thus far is the cell-wall-bound protein encoded by the gene Qid74, which may help to isolate the fungal cell from the negative effects of degrading enzymes and other toxins (Rosado et al. 2007).

Resistance to exogenous and endogenous toxic compounds is one of the keys to the ecological success of Trichoderma spp. (Lorito et al. 1996b). In fact, various strains belonging to this genera are among the most resistant microbes to natural and synthetic chemicals and toxins, and are able to rapidly degrade some of them, including hydrocarbons, chlorophenolic compounds, polysaccharides, and pesticides (Harman et al. 2004a and b; Rigot and Matsumura 2002). These beneficial fungi are among the first microbes to recolonize the soil after sterilization by methyl bromide, being more tolerant to this chemical than most other fungi or bacteria. Several integrated pest management (IPM) applications have been suggested for the control of fungal plant diseases by combining biological and chemical methods, including treatments of Trichoderma virens combined with metalaxyl or thiram to control the attack of Pythium ultimum on cotton or R. solani on tobacco (Chet et al. 1997), and of $T$. harzianum combined with captan used against Verticillium dahliae infecting potato (Chet and Inbar 1994). Moreover, many commercially applied Trichoderma strains are indicated as compatible with several fungicides, including captan, chlorothalonil, iprodione, thiophanate methyl, metalaxyl, chlorpyrifos, vinclozolin, (for instance, see T. harzianum T22 online). Increased resistance to drugs also has been described for Trichoderma spp. that attack immunocom- 
promised patients. Kratzer and collaborators (2006) demonstrated reduced activity of fluconazole and amphotericin B against clinical infections caused by Trichoderma isolates. In contrast, a novel beneficial treatment has been proposed using a strain of $T$. virens combined with an appropriate antifungal drug against the nail fungus Trichophyton rubrum (Omero et al. 2004)

The resistance of Trichoderma spp. to antimicrobial compounds also aids the fungi to stably colonize the roots and interact with plant tissues. This may result in a type of "priming" effect, with the plant being stimulated to produce various antimicrobial compounds, including pathogenesis-related proteins and phytoalexins, to which the biocontrol fungus appear to be at least partially tolerant (Yedidia et al. 1999, 2000, 2003). Also in this case, little is known about the mechanisms that permit Trichoderma spp. to survive in plant tissues without being apparently affected by defense compounds.

ATP-dependent permeases, composed of at least one highly conserved ATP-binding cassette (ABC) and one less conserved transmembrane (TM) domain, mediate the transport of many different substrates and, thus, the secretion of a wide variety of toxic compounds across biological membranes against a concentration gradient (Driessen et al. 2000). The differences in substrate specificity are determined by the TM domains (Chang 2003) which recognize and mediate the passage of the transported compounds.

Table 1. Primers used in this study ${ }^{\mathrm{a}}$

\begin{tabular}{ll}
\hline Primer name & \multicolumn{1}{c}{ Sequence $\left(\mathbf{5}^{\prime} \mathbf{-} \mathbf{3}^{\prime}\right)$} \\
\hline Pdasp1 & ATGGGKGYGAGCGGKGCWGGKAA \\
Pdasp2 & ATGGGKGYGTCCGGKCGWGGKAA \\
Pdsp1 & GCAGARGGYTGRTGGATSGT \\
Pdsp2 & GATGCTGGGCTGRTGGATGGT \\
TABC2for1 & TGGCTCCATCCAGGTTGAC \\
TABC2rev1 & CGGCAGCGAGCTTCGTAAG \\
SLABglII & AGATCTCACACGGAACTTGAATGTGGA \\
SLBStuI & AGGCTTTGTTAGTGGTAAGAGACCAC \\
SLCXbaI & TCTAGACTGTCCGTTTGTACGAAAG \\
SLDNarI & GGCGCCCAAGAGTTCCAATAACGACAG \\
HPHforw & CATGGATGCGATCGCTGC; \\
HPHrev & GTCTAGAAAGAAGGATTACCTC \\
TrAct1F & GGTATGGGTCAGAAGGACT \\
TrAct1R & CCTTTCGGACGTCGACATC \\
\hline
\end{tabular}

${ }^{\text {a }}$ Inserted restriction sites are underlined.
Several ABC transporter genes have been detected and characterized in filamentous fungi, and they have been associated with the movement of different substrates, including plant defence (i.e., phytotoxins), mating factors, antibiotics, chemical pesticides, and heavy metals (Andrade et al. 2000a and b; Del Sorbo et al. 2000, 2008; De Waard et al. 2006; Fleissner et al. 2002; Stergiopoulos et al. 2003; Urban et al. 1999). In particular, the role of the ABC transporter genes $A B C 1$ of Magnaporthe grisea and BcatrB of $B$. cinerea in pathogenicity and fungus-bacterium interaction, respectively, has been demonstrated (Schoonbeek et al. 2002; Urban et al. 1999). Very little is known about the function of these important permeases in biocontrol interactions mediated by bacteria (Abbas et al. 2004, Lee and Cooksey 2000; Martins dos Santos et al. 2004) and, further, there are no extended reports about the isolation and characterization of $\mathrm{ABC}$ transporter genes in biocontrol fungi.

In the present article, we suggest that $\mathrm{ABC}$ transporters are key factors in the multiple interactions established by Trichoderma biocontrol strains with other microbes and a potentially toxic or antagonistic environment. We report the cloning and functional characterization of the first $\mathrm{ABC}$ transporter gene from a biocontrol fungus, which was named Taabc2 and isolated from a Trichoderma atroviride strain (P1). We demonstrate by expression studies and targeted knock-out that this gene is required for a full antagonistic or biocontrol effect. It provides resistance or tolerance to some chemical fungicides as well as to pathogen toxins and, possibly, avoids autointoxication of the biocontrol agent by the inhibitory compounds produced during antagonistic interactions.

\section{RESULTS}

\section{Isolation and sequence analysis of a Trichoderma ABC transporter gene.}

We identified and cloned the full sequence of an ABC transporter gene named Taabc 2 from $T$. atroviride $\mathrm{P} 1$. We first isolated a 560-bp fragment by using combinations of degenerated primers designed (discussed below) on the conserved sequence of the $\mathrm{ABC}$ of fungi and yeast. The partial sequence showed very high homology or similarity to $\mathrm{ABC}$ transporter genes found in other fungi, with identity or positive scores ranging from 87 to $95 \%$ for genes from Gibberella zeae, Neurospora

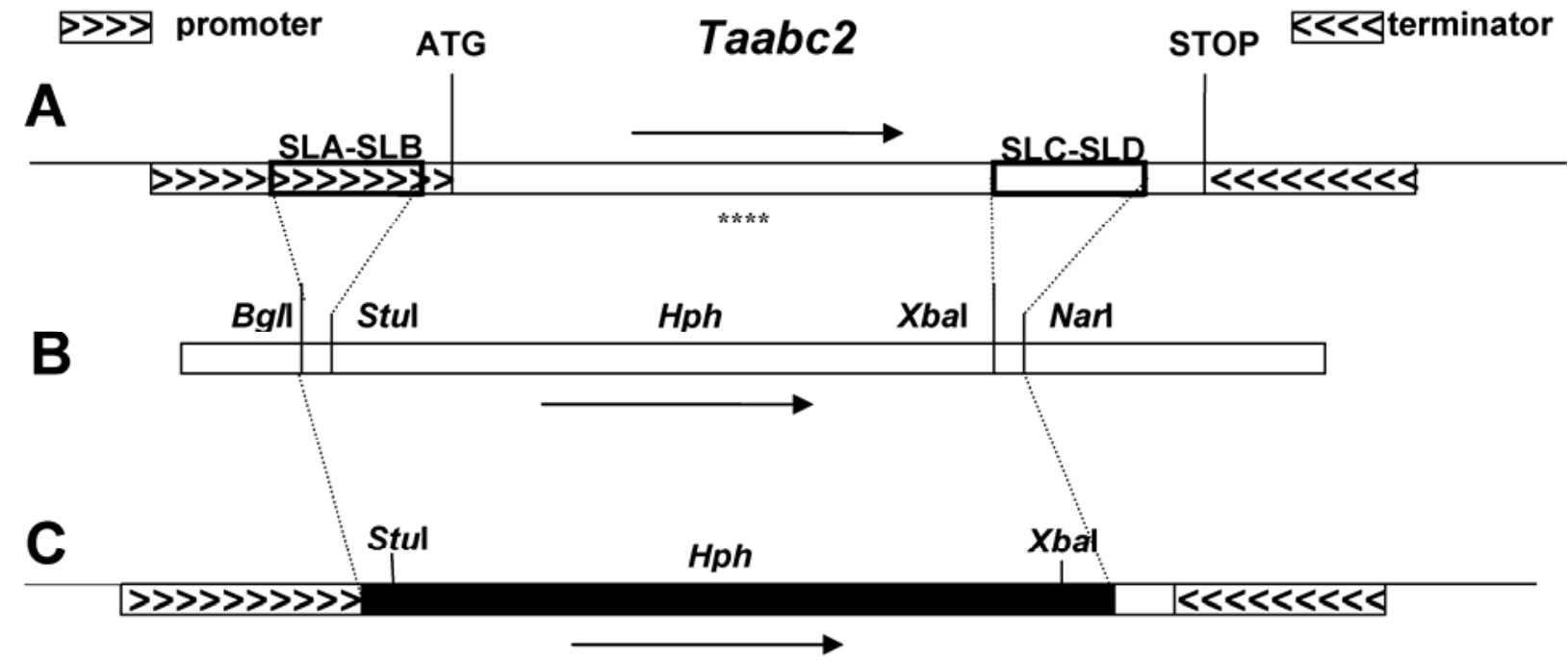

Fig 1. Targeted disruption of the Taabc 2 gene from Trichoderma atroviride P1. A, Wild-type Taabc 2 locus. Asterisks indicate the 393 -bp fragment used as a probe in Southern and Northern analyses. B, Hph cassette of the disruption vector containing homologous portions of Taabc2. C, Taabc2 locus after knockout. 
crassa, and Aspergillus nidulans (data not shown). Subsequently, the primers TABC2for1 and TABC2rev1 (Table 1), designed on the 560-bp fragment, were used to make a 393-bp probe (Fig. 1) for screening a genomic DNA library of T. atroviride $\mathrm{P} 1$. The $20-\mathrm{kb}$ insert of one selected library clone was digested with EcoRI, and the four fragments obtained were subcloned and sequenced. Two of these fragments combined provided a 6,535-bp sequence that contained the entire Taabc2 gene. It included a coding region of $4,270 \mathrm{bp}$, interrupted by two introns of $61 \mathrm{bp}($ at +697$)$ and 55 bp (at +1655), 1,624 bp of the promoter, and $641 \mathrm{bp}$ of the terminator. No restriction sites were found for BamHI, BglII, KpnI, and NotI. Southern analysis indicated that the gene is present as a single copy in the genome of $T$. atroviride P1 (Fig. 2A). The sequence of the Taabc 2 5'-upstream region contained two predicted TATA boxes (at -174 and -946) and several putative transcription-factor binding sites (HSF, NIT2, ADR1, STRE, MYC, MATa1, and StuAP), also found in the promoter of ech 42 , an endochitinase-encoding gene directly involved in mycoparasitism and biocontrol in the same T. atroviride strain (Lorito et al. 1996a; Mach et al. 1999; Woo et al. 1999). The BLASTP analysis of the predicted protein performed with the entire sequence (1,384 amino acids) confirmed the BLAST results obtained with the originally cloned 560-bp fragment. The proteins with the highest scores were $\mathrm{ABC}$ transporters from different phytopathogenic fungi, with the exception of $N$. crassa, and, in most cases, known to be involved in multidrug resistance (MDR) and transport of toxic compounds (Table 2). The best match to a protein with a known function was ATRB of A. nidulans, a multidrug transporter of many agricultural fungicides and some natural toxicants (Andrade et al. 2000a and b). One protein structure analysis identified 12 TM domains corresponding to the standard architecture of an $\mathrm{ABC}$ transporter with the longest cytosolic portion (amino acids 678 to 1,089) containing the ATP binding site. The ABC signature and the Walker A and Walker B domains were completely conserved, as indicated by the clustalW alignment with eight other ABC transporters from filamentous fungi (data not shown). The topology of the Taabc2-encoded protein matched that of a typical pleiotropic drug transporter ([NBD-TMS $]_{2}$ ), with the protein divided in two homologous halves each containing a nucleotidebinding domain (NBD) that precedes six TM domains.

\section{Expression analysis.}

Reverse-transcription polymerase chain reaction (RT-PCR) indicated that the expression of the T. atroviride Taabc 2 gene was stimulated only by benomyl and dicloran but not procloraz (Fig. 3A) at the concentrations tested. Taabc2 transcription was strongly activated when $T$. atroviride was grown in the presence of culture filtrates of the fungal plant pathogens $B$. cinerea, $R$. solani, or $P$. ultimum, as well as sterilized mycelia of $B$. cinerea or $R$. solani as the sole carbon source added to the growth medium (Fig. 3B).

Northern analysis confirmed that Taabc2 expression is induced by both the culture filtrates and biomass of $B$. cinerea or R. solani (Fig. 4, lanes 6 through 8) and, if T. atroviride is

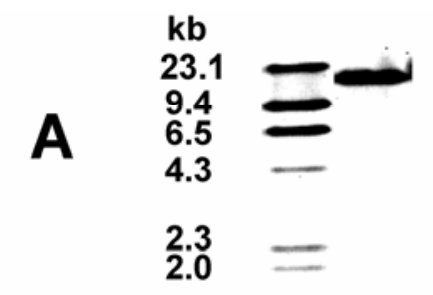

C

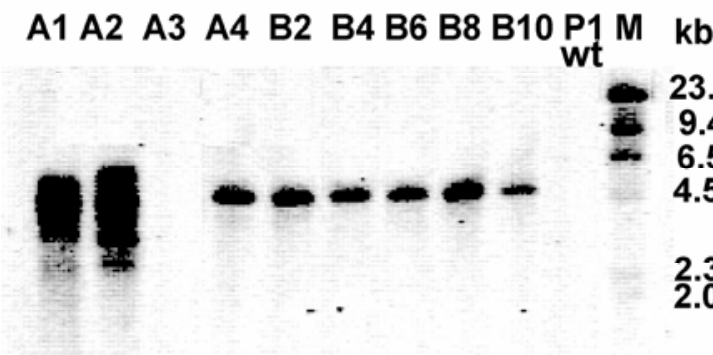

B

M A1 A2 A4 A5 A6 B2 B4 B6 B7 B8 B10 N

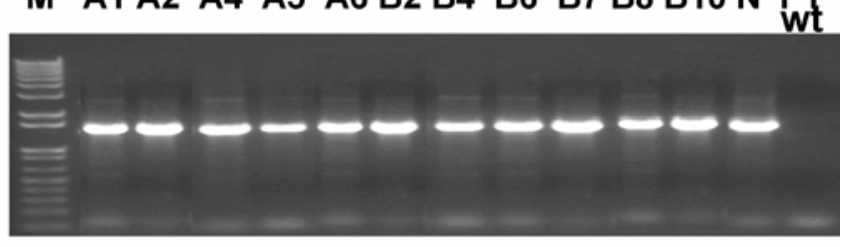

Fig. 2. Molecular characterization of the Taabc2 locus in Trichoderma atroviride P1 wild type (P1wt) and $\Delta T a a b c 2$ mutants. A, Southern analysis of T. atroviride P1wt Taabc2. Left lane, $\lambda$ HindIII marker (kb); right lane, strain P1wt genomic DNA digested with BamHI (no sites in the gene). B, Polymerase chain reaction products from amplification with primers specific for the $h p h$ cassette: $\mathrm{M}=1 \mathrm{~Kb}$ plus DNA ladder, A1 to A6 and B2 to B10 $=\Delta T a a b c 2$ mutants, $\mathrm{N}=$ pAN7-1 plasmid, P1wt = wild type. C, Southern analysis of DNA digested with XbaI and probed with the hph gene: A1 to A4 and B2 to B10 = $\triangle T a a b c 2$ mutants, P1wt = wild type, $\mathrm{M}=\lambda$ HindIII marker $(\mathrm{kb})$. D, Southern analysis of DNA digested with BglII and probed with the Taabc2 393 -bp probe: $\mathrm{M}=$ marker $(\mathrm{kb}), \mathrm{A} 1, \mathrm{~A} 4$, and $\mathrm{B} 2$ to $\mathrm{B} 10=\Delta T a a b c 2$ mutants, $\mathrm{P} 1 \mathrm{wt}=$ wild type. Experiments were performed at least twice.

Table 2. BlastP analysis of the deduced amino acid sequence of the Trichoderma atroviride Taabc2 gene.

\begin{tabular}{|c|c|c|c|c|}
\hline Identities (\%) & Positives $(\%)$ & Gaps (\%) & Accession no. & Matching ATP-binding cassette transporter proteins, source \\
\hline 75 & 87 & 0 & XP389006 & Hypothetical protein, Gibberella zeae \\
\hline 73 & 84 & 0 & XP380480 & Hypothetical protein, Neurospora crassa \\
\hline 71 & 82 & 0 & CAA93141 & ATRB, Aspergillus nidulans \\
\hline 70 & 82 & 0 & AA180009 & MFABC1, Monilinia fructicola \\
\hline 71 & 82 & 1 & CAB52402 & BCATRB, Botrytis cinerea \\
\hline 68 & 82 & 1 & BAB59028 & PMR5, Penicillium digitatum \\
\hline 66 & 79 & 1 & AAK62640 & ATR5, Mycosphaerella graminicola \\
\hline
\end{tabular}


exposed even at a relatively low concentration $(5 \mathrm{ppm})$, to beauvericin, a mycotoxin produced during habitat colonization by Beauveria bassiana and Fusarium spp. (Fig. 4, lanes 1 through 3). Interestingly, the addition of little amounts of glucose (Fig. 4, lanes 10 and 11), fructose (Fig. 4, lanes 12 and 13 ), and $N$-acetyl-D-glucosamine (Fig. 4 , lanes 14 through 16) stimulated accumulation of Taabc 2 mRNA.

Experiments with green fluorescent protein (GFP) mutants of $T$. atroviride $\mathrm{P} 1$, which contained the reporter gene under the control of the cloned Taabc 2 promoter ( $914 \mathrm{bp}$ ), confirmed the activation of the $\mathrm{ABC}$ transporter gene by dicloran, relatively low amounts of glucose, and fructose but not sucrose, added to the salt medium (SM), or by $R$. solani culture filtrate alone (Fig. 5). Dual culture tests performed on agarized $\mathrm{SM}+$ $1 \%$ (wt/vol) sucrose (SMS) medium as described by Zeilinger and associates (1999) also demonstrated that Taabc2 expression is directly stimulated by the presence of the living host $(R$. solani) already before the contact of the two confronting colonies (5 mm apart) (Fig. 5F), similarly to other biocontrolrelated genes (Mach et al. 1999; Zeilinger et al. 1999).

\section{Effect of targeted knock-out of Taabc2.}

Southern and PCR analysis confirmed the presence of the $h p h$ cassette (Figs. 1 and $2 \mathrm{~B}$ and $\mathrm{C}$ ) and the absence of a complete Taabc2 gene in the transformation progenies (Fig. 2D), the majority of which showed single and not multiple insertions (Fig. 2C). Five of the single-insert progenies were randomly selected, and the lack of Taabc2 transcripts was confirmed by Northern and RT-PCR analysis (data not shown) and used for the characterization of the $\triangle T a a b c 2$ mutant phenotype. The growth rate on SMS, potato dextrose agar
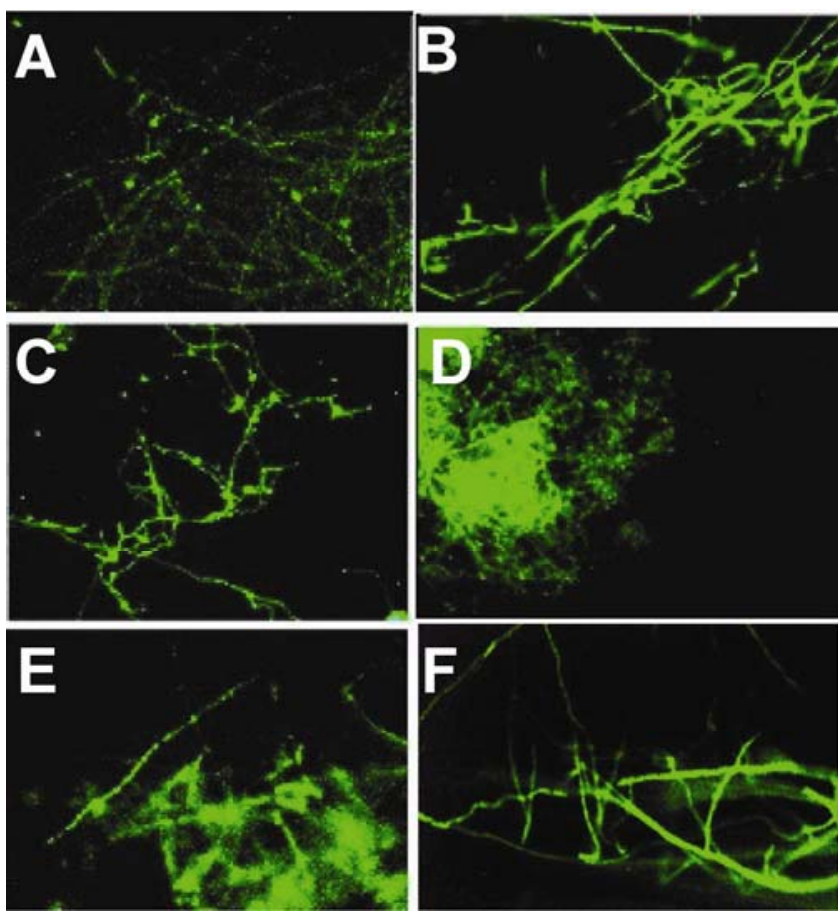

Fig 5. Induced fluorescence of Trichoderma atroviride P1 green fluorescent protein mutants, obtained by using the Taabc2 promoter and grown in the presence of: $\mathbf{A}$, salt medium $(\mathrm{SM})+1 \%(\mathrm{wt} / \mathrm{vol})$ sucrose; $\mathbf{B}$, $\mathrm{SM}+1 \%$ glucose; $\mathbf{C}, \mathbf{S M}+1 \%$ fructose; $\mathbf{D}, \mathbf{S M}+$ dicloran at $5 \mathrm{ppm} ; \mathbf{E}$ Rhizoctonia solani culture filtrate; and $\mathbf{F}, R$. solani mycelium (dual culture) before contact with the pathogen colony.

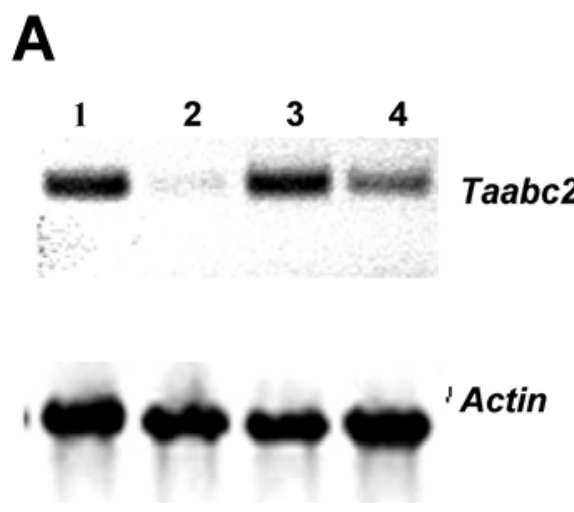

B

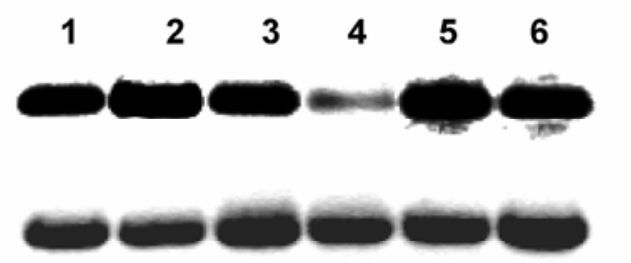

Taabc2

Actin

Fig. 3. Expression of the ATP-binding cassette transporter gene Taabc2 from Trichoderma atroviride P1 in the presence of different fungicides or fungal hosts, culture filtrates (CF), or mycelia. A. Growth substrate, salt medium + 1\% (wt/vol) sucrose (SMS), contained benomyl, 50 ppm (lane 1); procloraz, 50 ppm (lane 2); dicloran, $50 \mathrm{ppm}$ (lane 3); and no fungicide control with SMS alone (lane 4). B, Growth substrate SMS contained Botrytis cinerea CF (lane 1), Rhizoctonia solani CF (lane 2), Pythium ultimum CF (lane 3), no amendment control with SMS alone (lane 4), B. cinerea mycelia at 1\% (wt/vol) (lane 5), and $R$. solani mycelia at $1 \%(\mathrm{wt} / \mathrm{vol})($ lane 6$)$.
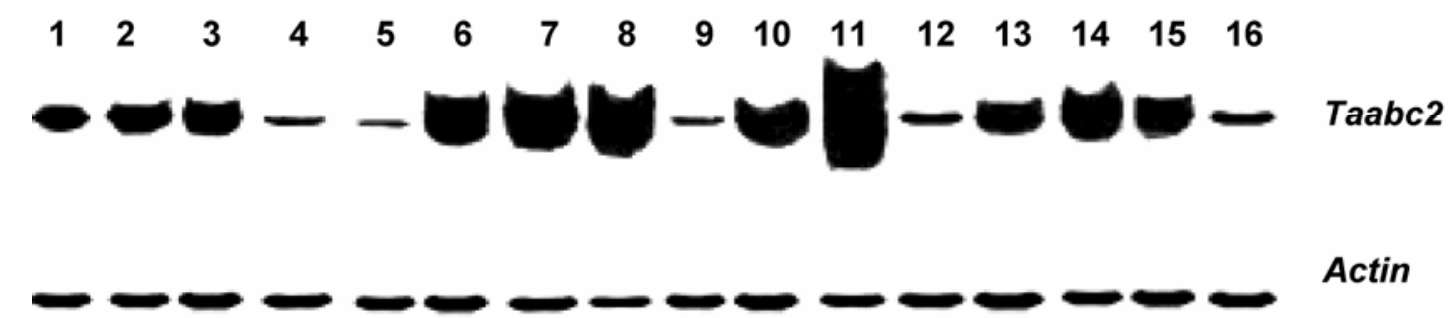

Fig. 4. Northern analysis of Taabc2 expression when Trichoderma atroviride P1 was grown in the presence of different fungal toxins, pathogen culture filtrates (CF) or mycelia, or with different carbon sources. Lane 1, salt medium + 1\% (wt/vol) sucrose (SMS) + beauvericin at $5 \mathrm{ppm}$ for $10 \mathrm{~min}$ before RNA extraction; lane 2, SMS + beauvericin at $5 \mathrm{ppm}$ for $20 \mathrm{~min}$ before RNA extraction; lane 3, SMS + beauvericin at 5 ppm for 40 min before RNA extraction; lane 4, no treatment control on SMS (1\% sucrose) only; lane 5, no treatment control on SMS (3\% sucrose) only; lane 6, SMS + Botrytis cinerea mycelia; lane 7, SMS + Rhizoctonia solani CF; lane 8, SMS + B. cinerea CF; lane 9, no treatment control on SMS (1\% sucrose) only; lane 10, salt medium (SM) + $0.2 \%$ glucose; lane $11, \mathrm{SM}+4 \%$ glucose; lane $12, \mathrm{SM}+0.5 \%$ fructose; lane $13, \mathrm{SM}+1 \%$ fructose; lane $14, \mathrm{SM}+0.1 \mathrm{M}$ N-acetyl-D-glucosamine (NAG); lane 15, SM + 0.01 M NAG; lane 16, SM + 0.001 M NAG. 
(PDA), or potato dextrose broth (PDB) of the selected knockout mutants was substantially the same as the wild-type P1 (P1wt) (data not shown), with the exception of $\Delta$ Taabc2B6 on PDB. In all cases, the conidia produced by the mutants were similar in color, form, and size to those of P1wt but had a germination rate reduced by approximately 30\%. In contrast to the wild type, the mutants were completely inhibited by the chemical fungicide dicloran applied at a relatively low concentration (10 ppm) (Fig. 6A) and grew poorly in salt media containing only $1 \%$ fructose, $0.2 \%$ glucose, or $0.5 \%$ colloidal chitin as the sole carbon source (Fig. 6B). These results are in agreement with the fact that the above drug and sugars at the applied concentrations stimulate the expression of the native Taabc2 gene.

In order to investigate the role of $T a a b c 2$ during mycoparasitism and antagonism, Botrytis cinerea, R. solani, and P. ulti- mum were grown in PDB liquid media, the fungal biomass was removed, and the culture filtrates were inoculated with spores of the T. atroviride $\Delta T a a b c 2$ mutants, $\mathrm{P} 1$ containing the $h p h$ cassette, or P1wt (Fig. 7). Considering the amount of mycelia recovered after 1 week of incubation compared with the wild type and controls (fungal biomass obtained in P1wt culture filtrates) (Fig. 7), all the mutants tested grew less in the presence of metabolites and molecules that may stimulate mycoparasitism or antagonism (i.e., cell wall fragments) accumulated in the culture filtrates by any of the phytopathogenic fungi (Fig. 7 , representative mutants). Similar results were obtained when T. atroviride $\mathrm{P} 1 \Delta T a a b c 2$ mutants and the wild type were exposed to the toxins beauvericin, fusaproliferin, and aflatoxin B1, B2, and G1 produced by B. bassiana or Fusarium spp. during both plant tissue colonization and antagonistic or mycoparasitic interactions with Trichoderma spp. (Fig. 8). $\Delta$ Taabc2
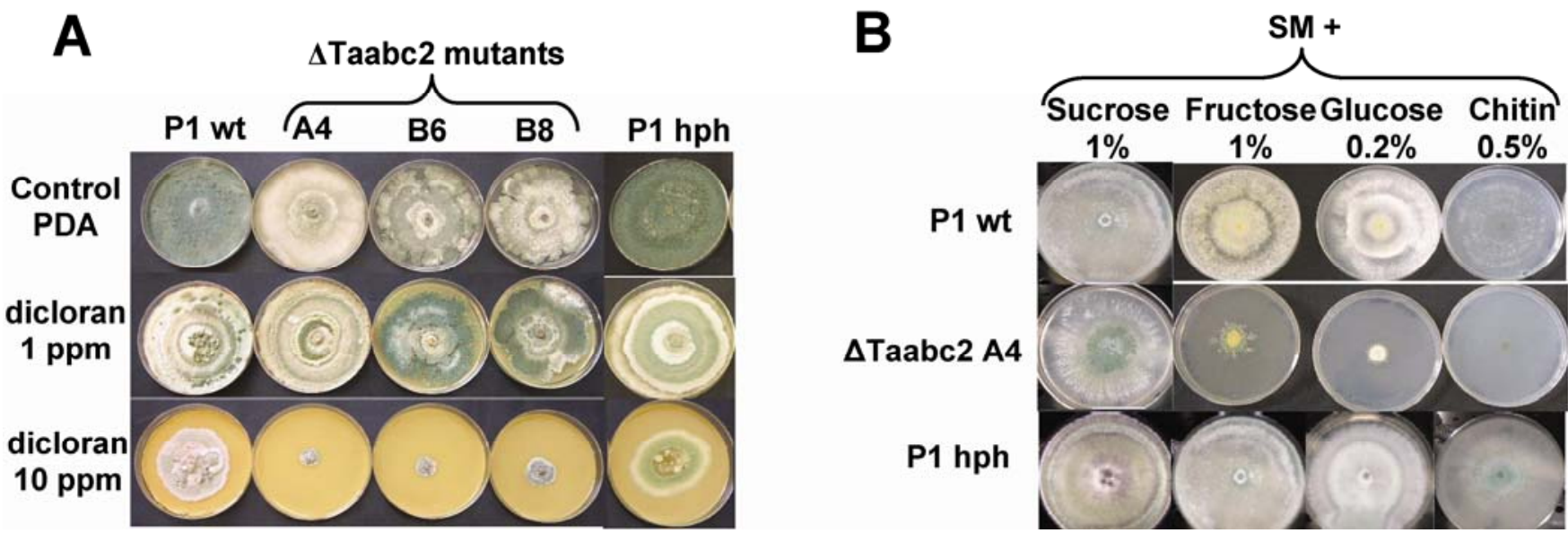

Fig. 6. Effect of Taabc2 knock-out on the growth of Trichoderma atroviride P1 on different agarized substrates. A, Potato dextrose agar (PDA) containing no fungicide (Control) or dicloran (1 and $10 \mathrm{ppm})$; B, salt medium (SM) containing the indicated sugar with compound as the sole carbon source. Controls include a representative mutant transformed with the empty vector (P1 hph). Fungi were observed for approximately 1 week, until the fastest growing isolate reached the petri plate edge.

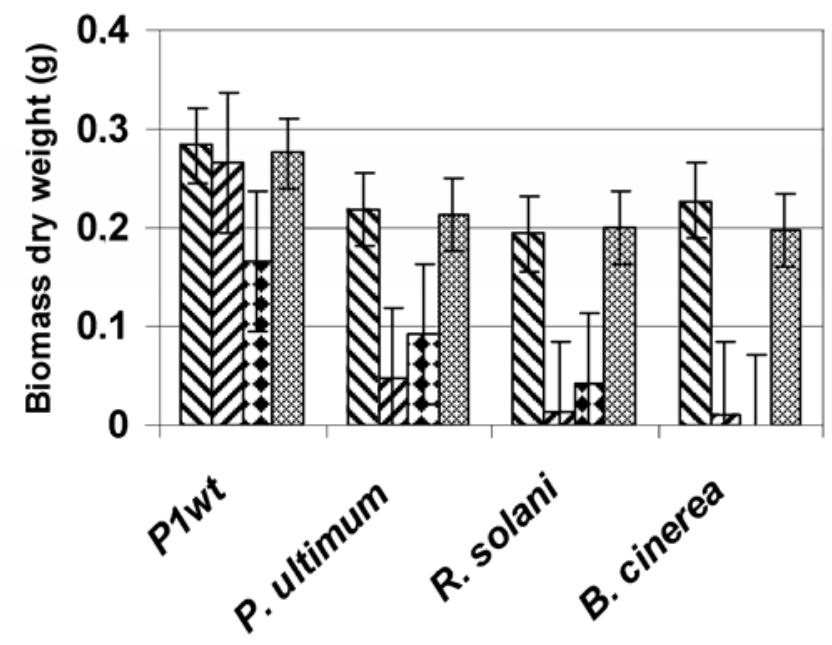

\section{Culture filtrate used to grow T. atroviride strains}

\section{NP1 wt}

Fig. 7. Comparative growth of Trichoderma atroviride strains P1 wild type (P1wt) and $\Delta T a a b c 2$ mutants in the culture filtrates of P1 and three plant pathogenic fungi. Fungal biomass was obtained in potato dextrose broth for all the fungi and removed after 10 days of incubation. The culture filtrate was filter sterilized, then inoculated with spores of the T. atroviride strains. After 7 days, the $\Delta T a a b c 2$ mutants, P1 hph, and P1wt biomass were collected, lyophilized, and weighed. Only two representative mutants are shown. Controls include biomass obtained in culture filtrates from P1wt instead of a pathogen, and a representative mutant transformed with the empty vector $(\mathrm{P} 1 \mathrm{hph})$. Bars indicate standard deviation from three experiments with five replicates per treatment. 
mutants were much less tolerant than the wild type to all tested mycotoxins and, in particular, to aflatoxins B1 and G1 and fusaproliferin (Fig. 8).

The effect of the Taabc2 knock-out on the direct antagonistic ability of $T$. atroviride was also investigated by using a standard dual-culture assay, in which mutants or the wild-type strain were allowed to grow opposite to different fungal hosts on agarized substrate for at least 1 month. Also, in this case, the ability of the selected $\triangle T a a b c 2$ mutants to overgrow, inhibit, and degrade the mycelia of $B$. cinerea, $R$. solani, or P. ultimum was strongly reduced compared with the effective mycoparasitic action of the untransformed strain P1wt (Fig. 9). Coherently, the lack of Taabc2 function significantly reduced the protective effect of $T$. atroviride $\mathrm{P} 1$ against $R$. solani or $P$. ultimum attack on tomato plants (Fig. 10). The biocontrol effect was reduced by approximately $25 \%$ against the Oomycete (Fig. 10A) and completely lost against the Basidiomycete (Fig. $10 \mathrm{~B})$. This is in agreement with the fact that $R$. solani culture filtrate produced both a high level of Taabc2 expression (Figs. 3 , lane 2 and 4, lane 7) and a significant inhibition of the $\triangle T a a b c 2$ mutant growth (Fig. 7).

\section{DISCUSSION}

Fungi belonging to the genus Trichoderma are known and extensively studied because they are capable of actively interacting with different substrates and living organisms, including plants and microbes (Benítez et al. 2004; Harman et al. 2004a). We considered that the innate ability of these fungi to tolerate relatively high concentrations of a variety of synthetic and natural toxic compounds, including its own antibiotics, and also to act as strong competitors of different microorganisms depends on efficient cell detoxification mechanisms supported by a complex system of membrane pumps. In a recent proteomic study, we found that, in different Trichoderma spp., there are a number of $\mathrm{ABC}$ transporter genes upregulated during the three-way interaction with various plants and fungal pathogens, which possibly supports both antagonistic activity and root colonization (Marra et al. 2006).
In this work, we fully sequenced and characterized the first ABC transporter gene from the Trichoderma genus and named it Taabc2. Sequence similarities indicate that this gene belongs to a group of pleiotropic drug resistance (PDR) factors with overlapping substrate specificity, including AtrB, BcatrB, $M$ fatrB, and Pmr5. The highest homology scores with characterized ABC proteins (Table 2) were with ATRB from A. nidulans, MFABC1 (MFATRB) from Monilinia fructicola, BCATRB of B. cinerea, and PMR5 from Penicillium digitatum, suggesting that $\mathrm{TAABC} 2$ has a role in the resistance to and transport of various toxins and antibiotics. In fact, there seems to be a general correspondence, at least in fungi, among the sequences of $\mathrm{ABC}$ transporters and their physiological functions (i.e., in regards to the class of transported substrates) (De Waard et al. 2006). AtrB was found to encode for an MDR transporter capable of providing resistance to azole fungicides, cycloheximide, and pisatin (Andrade et al. 2000a and b; Angermayr et al. 1999; Del Sorbo et al. 1997). Similarly, $M f a b c l$ and Pmr5 are known to be involved in the resistance to demethylation inhibitor fungicides, whereas $\triangle P m r 5$ knock-out mutants also displayed increased sensitivity to thiabendazole, benomyl, dithianon, resveratrol, and camptothecin (Nakaume et al. 2002; Schnabel et al. 2003). In T. atroviride, Taabc2 was upregulated by benomyl and dicloran (Fig. 3) but not by the azole fungicide procloraz. Accordingly, $\Delta T a a b c 2$ mutants were more sensitive than the wild type to dicloran, indicating a role of this gene in the mechanisms of cell detoxification from xenobiotic compounds. Another function of Taabc 2 could be to make $T$. atroviride more competitive toward other microbes by providing tolerance to bacterial or fungal toxins and by supporting the secretion of the biocontrol agent antibiotics (selfdetoxification function). The expression of this gene was stimulated by beauvericin (Fig. 4), and the relative knock-out mutants were more sensitive to this and other mycotoxins, including aflatoxins B1, B2, and G1, as well as fusaproliferin (Fig. 8). Notably, the addition of beauvericin at up to $10 \mathrm{ppm}$ did not interfere with the mycoparasitic and antagonistic activity of the wild-type strain against $B$. cinerea and different Fusarium spp. that are natural beauvericin producers (data not

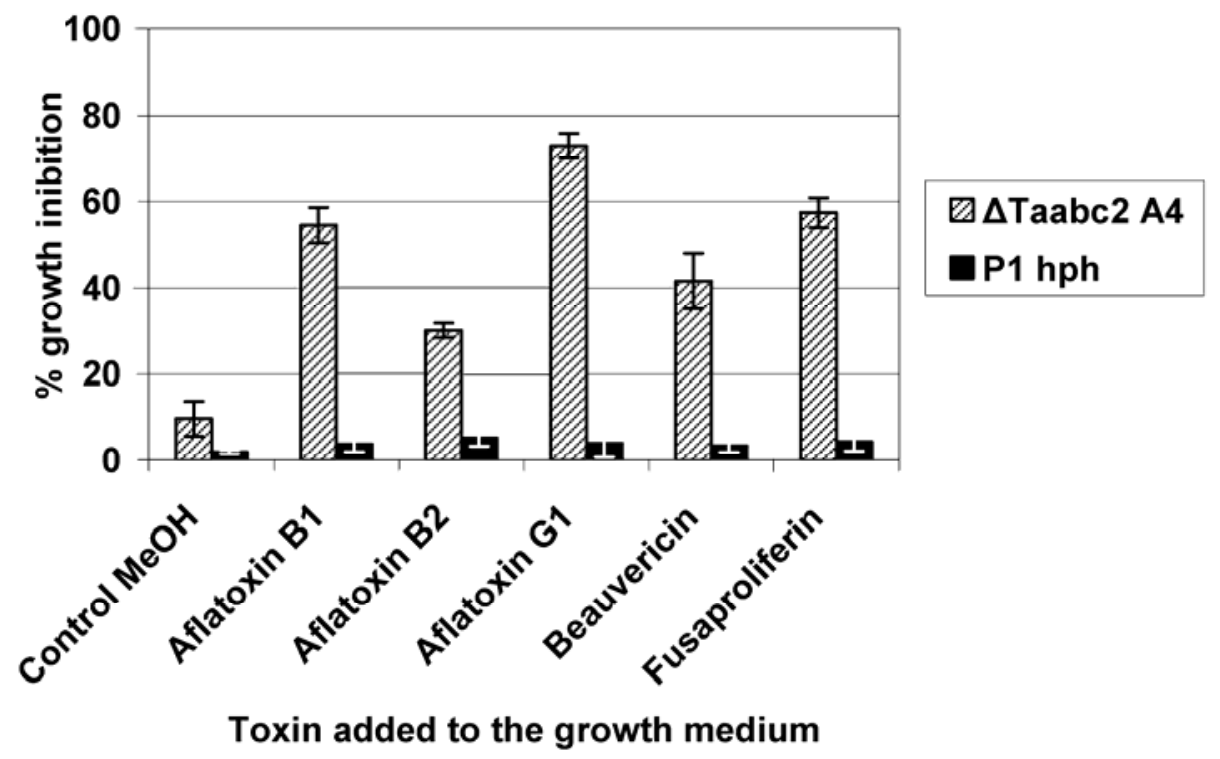

Fig. 8. Effect of different mycotoxins on the mycelial growth of a representative Trichoderma atroviride $\Delta$ Taabc 2 mutant, indicated as percent inhibition relative to the growth of the wild-type strain P1 subjected to the same treatments. The tests were performed on agarized salt medium $+1 \%$ sucrose (SMS). Toxins were applied at a concentration of 5 ppm, which did not produce significant growth inhibition of the wild-type P1 (data not shown). Controls include treatment with the solvent used for dissolving the mycotoxins ( $\mathrm{MeOH})$ and a representative mutant transformed with the empty vector (P1 hph). Fungi were grown for approximately 1 week, until the fastest growing strain reached the petri plate edge. Bars indicate standard deviation from three experiments with five replicates per treatment. 
shown). Also, in the case of A. nidulans, Andrade and colleagues (2000b) demonstrated that AtrD protects the cell from valinomycin, a potassium-selective cyclododecadepsipeptide ionophore that is structurally related to beauvericin. BcatrB of $B$. cinerea, another $\mathrm{ABC}$ transporter gene with high similarity to $T a a b c 2$, was found to be involved in competition between microorganisms (Schoonbeek et al. 2002). In particular, this gene protected the pathogenic fungus from phenazine antibiotics produced by Pseudomonas spp. Similarly, the ability of Erwinia chrysanthemi to compete in planta against saprophytic bacteria was reduced by the inactivation of the $\mathrm{ABC}$ transporter gene ybiT (Llama-Palacios et al. 2002).

Taabc 2 may also support the secretion of T. atroviride's own mycotoxins, as demonstrated for CFP of Cercospora kikuchii (Callahan et al. 1999) and PhlE of Pseudomonas fluorescens (Abbas et al. 2004), even though the T. atroviride permease belongs to the $\mathrm{ABC}$ transporter and not to the major facilitator superfamily. We didn't specifically investigate this hypothesis because of the large variety of antibiotics produced by strain P1, but there are several indications in favor of it. i) Taabc2 was co-induced with biocontrol-related "virulence factors" (enzymes and antibiotics) (described below) in conditions of carbohydrate starvation given by media containing low amounts of glucose, fructose, or chitin as the sole carbon source (Mach et al. 1999), as well as in the presence of mycotoxins and metabolites produced by other microbes (Figs. 3 and 4). ii) The $5^{\prime}$ upstream region of Taabc 2 contains putative consensus sequences, such as stress-related elements (STRE) and mycoparasitism-related elements (MYC1-3) (Cortes et al. 1998; Delgado-Jarana et al. 2002), typically found on the promoter of mycoparasitism-related genes also in strain P1 (Lorito et al. 1996a; Woo et al. 1999). iii) The $\Delta$ Taabc2 mutants grew and competed poorly in conditions conducive to the production of antibiotics, such as starvation (Figs. 6 and 9) or in the presence of signals from fungal hosts $(R$. solani, $B$. cinerea, and Pythium ultimum) (Fig. 7). In fact, the lack of function of this particular $\mathrm{ABC}$ transporter associated with the stimulated synthesis of $T$. atroviride's own toxins may have caused an auto-intoxication of the fungus (Figs. 6, 7, 9, and 10) similar to that reported by Abbas and associates (2004) about the role of the permease-encoding PhlE gene in Pseudomonas fluorescens. Accordingly, the growth on glucose-rich PDA or PDB medium was not impaired (Figs. 6 and 7), because the expression of many mycoparasitism-related genes is repressed in high-carbon conditions (Lorito et al. 1996a). iv) We have evidence that one of the selected $\triangle T a a b c 2$ knock-out mutants is unable to release 6 -pentyl- $\alpha$-pyrone, a volatile antibiotic normally secreted by the wild-type strain during mycoparasitism (F. Vinale and M. Lorito, unpublished data).

A variety of "offensive" compounds secreted by antagonistic fungi have been identified not only in Trichoderma spp. but also in other mycoparasitic species. These "virulence factors" include a large number of different enzymes (mainly chitinases, glucanases, proteases, and cellulases) (Benítez et al. 2004; Brunner et al. 2003; Howell 2003; Mendoza-Mendoza et al. 2003; Viterbo et al. 2002; Woo et al. 1999) and up to 200 different antibiotics and mycotoxins (Daniel and Filho 2007; Sivasithamparam et al. 1998; Vey et al. 2001). However, a successful interaction, antagonistic or mycoparasitic with other microbes or symbiotic with the plant, requires the activation of defence mechanisms for cell detoxification and protection of the fungus metabolism and structures. Unfortunately, very little

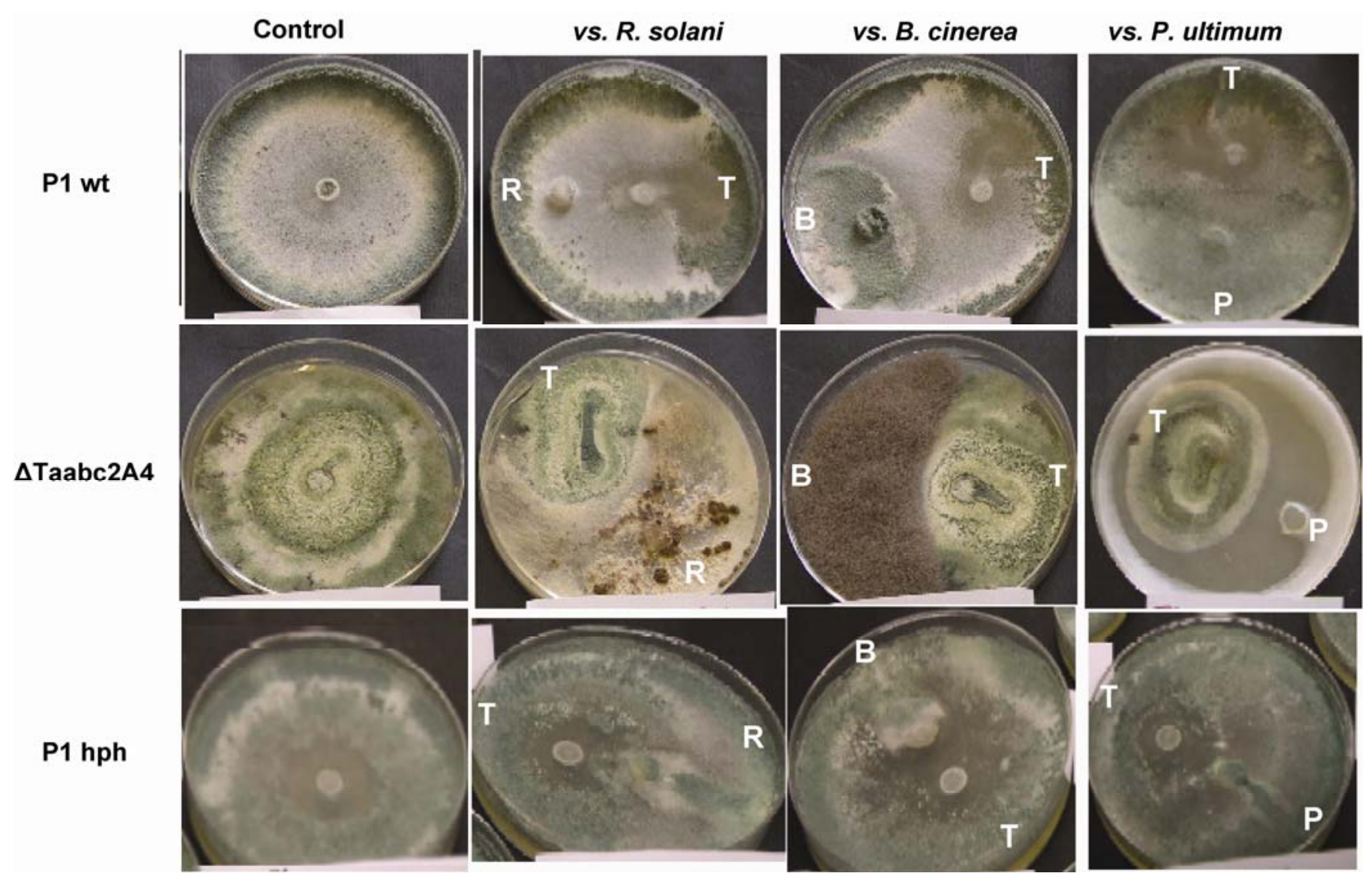

Fig. 9. Antagonistic activity in vitro of Trichoderma atroviride wild-type strain P1 (P1wt) and a representative $\Delta$ Taabc2 mutant against various plant pathogens on salt medium $+1 \%$ sucrose (SMS). Confrontation assays were left to run for at least 1 month. Control: T. atroviride P1wt, $\Delta$ Taabc2A4, and a representative empty vector-transformed mutant ( $\mathrm{P} 1 \mathrm{hph})$, grown alone without plant pathogen. Letters indicate the site of the inoculum of T. atroviride $\mathrm{P} 1 \mathrm{wt}$ or the indicated mutant (T), Rhizoctonia solani (R), Botrytis cinerea (B), or Pythium ultimum (P). 
information is available today on the "protective factors" used by biocontrol fungi, including Trichoderma spp. For instance, it has been suggested that a cell-wall-bound protein named QID74 (Rosado et al. 2007) or some specific proteases (Delgado-Jarana et al. 2000) avoid the degradation of T. harzianum cell walls by enzymes released during mycoparasitism. On the other hand, antagonistic fungi and, in particular, mycoparasitic species manage in many cases to be tolerant to a variety of mycotoxins and antibiotics, including their own, and also to some chemical fungicides. Therefore, it is likely that these microbes possess an extensive and effective membrane pump system that actively removes many different harmful compounds from the cell, which may explain at least in part the ecological success of Trichoderma spp. It has been demonstrated that $\mathrm{ABC}$ transporter-encoding genes support both the growth and the pathogenic action of important plant pests such as $B$. cinerea, Mycosphaerella graminicola, and Magnaporthe grisea (Del Sorbo et al. 2008; Schoonbeek et al 2002; Stergiopoulos et al. 2003; Urban et al. 1999). Similarly, targeted knock-out of the Taabc2 gene strongly reduced the antagonistic activity of a T. atroviride strain, both in vitro and in vivo, against fungi belonging to diverse fungal groups-an Ascomycete, a Basidiomycete, and an Oomycete.

The data presented in this article indicate that TAABC 2 and, in general, ABC transporters help T. atroviride to successfully antagonize or colonize various pathogens or plants in many different environmental conditions (Marra et al. 2006) and, thus, play a key role in Trichoderma-mediated biocontrol.. Ob-

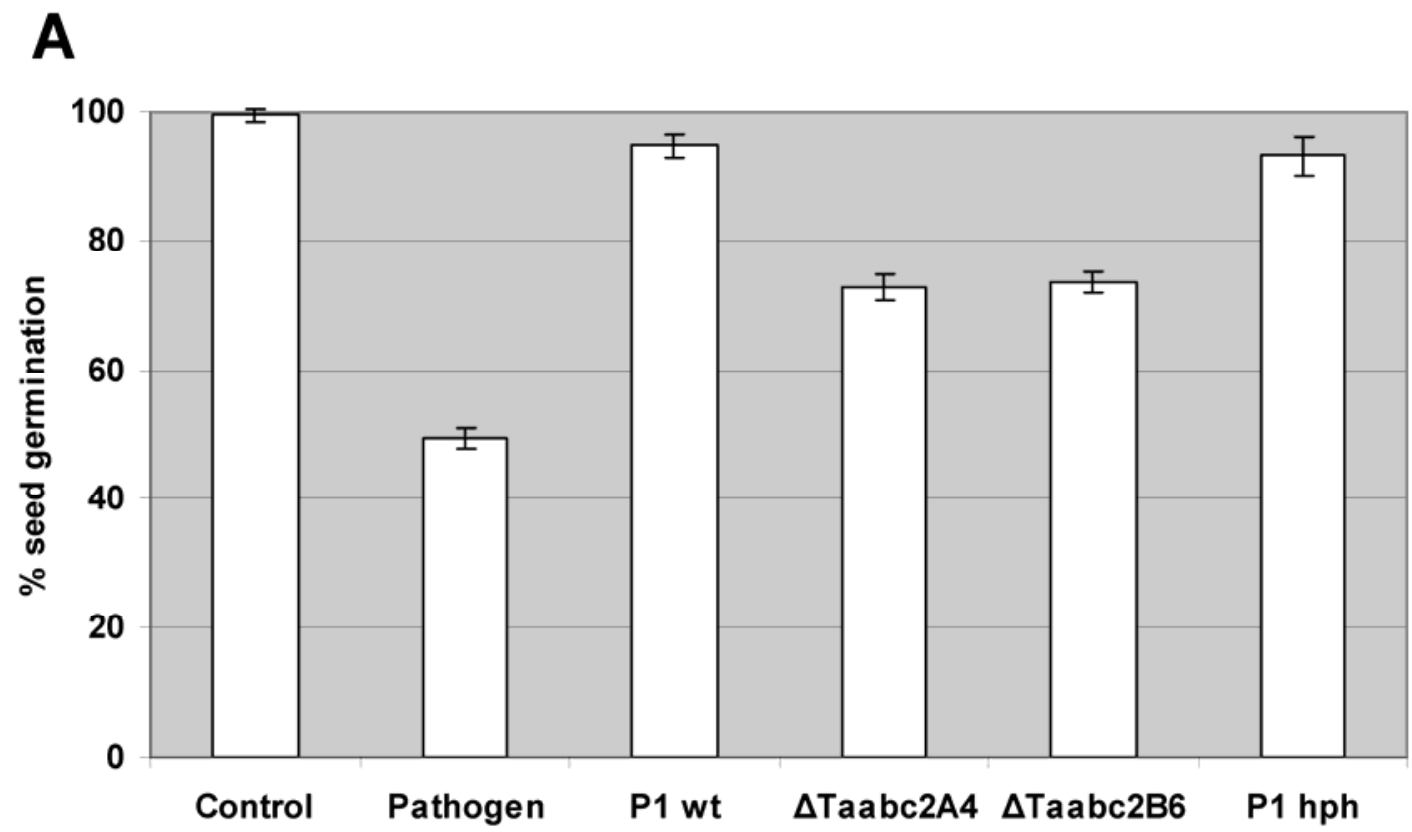

B

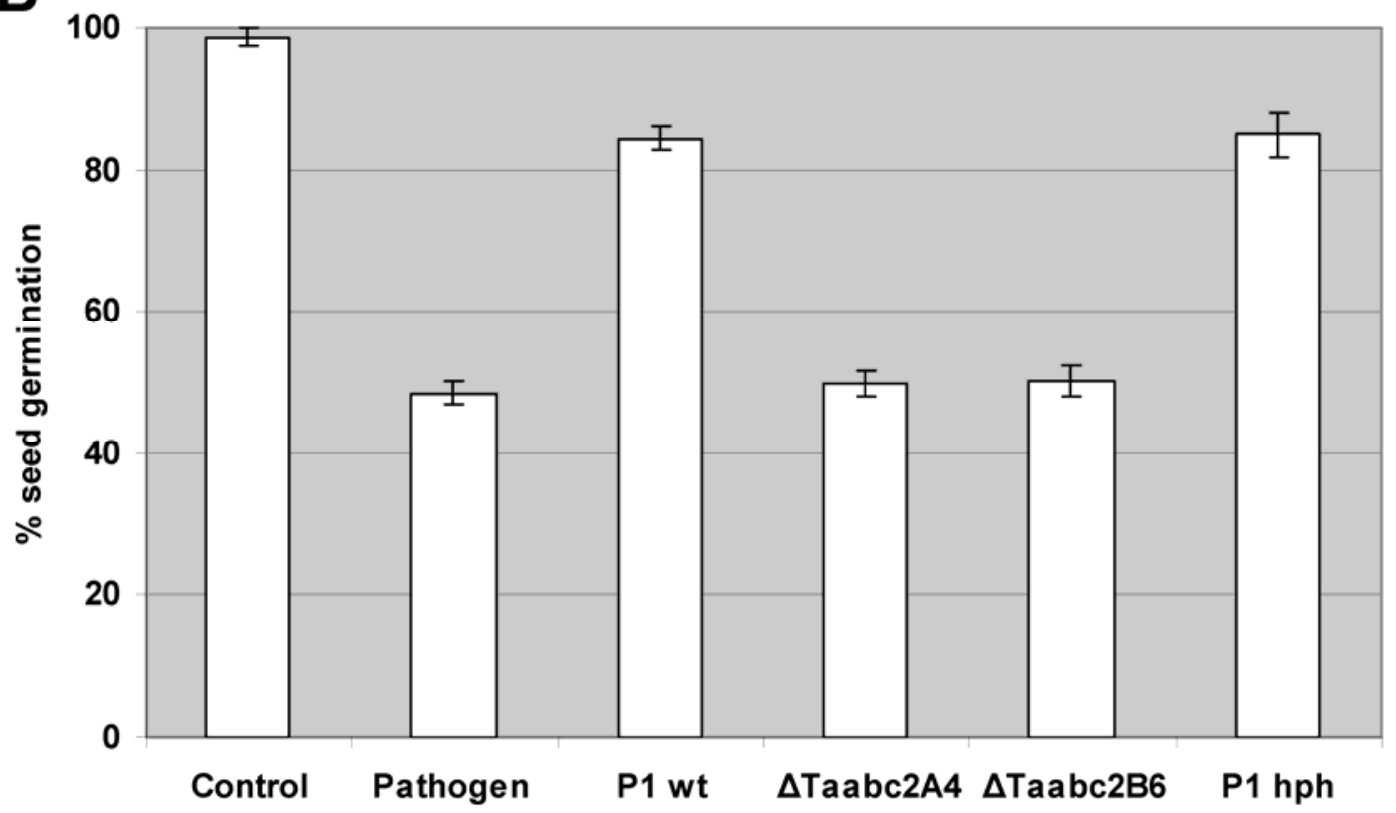

Fig. 10. Effect of Taabc 2 knock-out on the in vivo biocontrol activity of Trichoderma atroviride P1. The wild-type strain (P1wt) and two representative $\Delta$ Taabc 2 mutants were applied as a seed coating, and the plant protection effect is indicated as the percentage of tomato seed germination in soil infested with $\mathbf{A}, P y$ thium ultimum or B, Rhizoctonia solani. Control = no fungal treatment (no pathogen no antagonist); pathogen = pathogen alone without seed treatment with T. atroviride $; \mathrm{P} 1 \mathrm{hph}=$ seed treatment with a representative empty vector-transformed mutant instead of P1wt or a $\Delta T a a b c 2$ strain. The standard deviation bars were obtained from at least three different experiments, with five replicates and a total of 15 treated seeds per treatment. 
viously, the genes encoding for these permeases may prove to be useful new tools for genetic improvement of microbial agents or disease resistance in plant.

\section{MATERIAL AND METHODS}

\section{Fungal strains.}

T. atroviride P1 (ATCC 74058), isolated from wood chips and selected for its tolerance to the fungicide iprodione (Tronsmo 1991), was used in this study. Pathogen B. cinerea 309 isolated from tobacco, $R$. solani 1556 from tomato, and Pythium ultimum 2312 from tomato were obtained from the culture collection of the Department ArBoPaVe of the University of Naples. Fungi were grown on PDA, colonies were allowed to sporulate, and conidia were harvested and used to inoculate liquid media $(100 \mathrm{ml})$ in glass flasks $\left(1 \times 10^{8}\right.$ spores/ flask), which were incubated at $25^{\circ} \mathrm{C}$ on a rotary shaker at 150 rpm. PDB was used for the pathogens, whereas the T. atroviride wild type and mutants were grown in SMS (composition per liter: $680 \mathrm{mg}$ of $\mathrm{KH}_{2} \mathrm{PO}_{4}, 870 \mathrm{mg}$ of $\mathrm{K}_{2} \mathrm{HPO}_{4}, 200 \mathrm{mg}$ of $\mathrm{KCl}$, $1 \mathrm{~g}$ of $\mathrm{NH}_{4} \mathrm{NO}_{3}, 200 \mathrm{mg}$ of $\mathrm{CaCl}_{2}, 200 \mathrm{mg}$ of $\mathrm{MgSO}_{4} \times 7 \mathrm{H}_{2} \mathrm{O}$, $2 \mathrm{mg}$ of $\mathrm{FeSO}_{4}, 2 \mathrm{mg}$ of $\mathrm{MnSO}_{4}, 2 \mathrm{mg}$ of $\mathrm{ZnSO}_{4}$, and $10 \mathrm{~g}$ of sucrose) (Schirmbock et al. 1994) unless differently indicated. This media was eventually amended with glucose, fructose, or $\mathrm{N}$-acetyl-D-glucosamine (NAG) instead of sucrose, or with toxins, fungicides, pathogen mycelia, and so on.

\section{Cloning of $\mathrm{ABC}$ transporter genes.}

Fungal DNA extraction was performed from mycelia collected by filtration with Miracloth (Calbiochem, La Jolla, CA, U.S.A.) and by using a standard phenol-chloroform procedure (Sambrook et al. 1989). Degenerated primers Pdasp1, Pdasp2, Pdsp1, and Pdsp2 (Table 1) were synthesized based on the conserved $\mathrm{ABC}$ sequences of fungal and yeast $\mathrm{ABC}$ transporter genes. PCR amplification was performed, unless differently indicated, by using: $100 \mathrm{ng}$ of $T$. atroviride P1 DNA as template. Amplicons of approximately $500 \mathrm{bp}$ were excised from the gel and cloned in the pGEMT Easy vector (Promega Corp., Madison, WI, U.S.A.). The resulting plasmids were sequenced by MWG Biotech AG (Ebersberg, Germany) and subjected to BLASTX analysis. Plasmid DNA was purified from Escherichia coli cultures using an alkaline lysis method (Sambrook et al. 1989) or a Qiaprep spin miniprep kit (Qiagen, Hilden, Germany) following the manufacturer's directions. Primers TABC2for1 and TABC2rev1 (Table 1) were designed on the sequence of one of the clones that matched $\mathrm{ABC}$ transporter genes and used to isolate the entire corresponding gene (named Taabc2). This probe was obtained by using the PCR digoxigenin (DIG) system kit (Roche, Basel, Switzerland). The 393-bp fragment obtained was used to screen a T. atroviride P1 Lambda genomic DNA library following the protocol described on the Lambda Library user manual (Clontech, Mountain View, CA, U.S.A.).

\section{Southern analysis of the Taabc 2 locus.}

DNA $(5 \mu \mathrm{g})$ of $T$. atroviride P1wt or of the selected transformants was digested overnight with the appropriate restriction enzyme (Promega Corp.), separated by electrophoresis on agarose $(1 \%)$ gel, and transferred onto Hybond $\mathrm{N}^{+}$nylon membrane (Amersham Biosciences, Uppsala, Sweden). Hybridization and visualization were performed following the manufacturer's directions (Roche); 20 ng of the 393-bp DIG-labeled probe were used per milliliter of the hybridization buffer DIG easy $\mathrm{Hyb}$ and were left to react at $42^{\circ} \mathrm{C}$ for $18 \mathrm{~h}$. Membranes were washed twice for $15 \mathrm{~min}$ in $2 \times \mathrm{SSC}(1 \times \mathrm{SSC}$ is $0.15 \mathrm{M} \mathrm{NaCl}$ plus $0.015 \mathrm{M}$ sodium citrate) with $0.1 \%$ sodium dodecyl sulfate (SDS) at room temperature and twice for $30 \mathrm{~min}$ in $0.1 \times$
SSC with $0.1 \%$ SDS at $42^{\circ} \mathrm{C}$. Band detection was obtained according to the manufacturer's instructions (Roche) and using the antiDIG Ap-conjugate antibody and the substrate CDPStar.

\section{Gene expression analysis.}

Induction of $\mathrm{ABC}$ transporter genes in T. atroviride $\mathrm{P} 1$ was determined by RT-PCR and Northern analysis. RNA extraction was performed on mycelia grown for 2 days in SMS augmented with benomyl (50 ppm) (DuPont Agricultural Products, Wilmington, DE, U.S.A.), procloraz (50 ppm) (Aventis Crop Science, Wolfenbuttel, Germany), dicloran (50 ppm) (Sariaf Gowan, Faenza, Italy), autoclaved $B$. cinerea mycelia $(1 \% \mathrm{wt} / \mathrm{vol})$, or autoclaved $R$. solani mycelia $(1 \% \mathrm{wt} / \mathrm{vol})$. For the other tested conditions, the fungus was grown in SMS for $48 \mathrm{~h}$ and then exposed for 10,20 , or $40 \mathrm{~min}$ to beauvericin $(5 \mathrm{ppm})$ (Sigma-Aldrich, St. Louis) prior to RNA extraction; salt medium $(\mathrm{SM})+0.2 \%$ glucose $; \mathrm{SM}+4 \%$ glucose $; \mathrm{SM}+0.5 \%$ fructose; $\mathrm{SM}+1 \%$ fructose; $\mathrm{SM}+0.1,0.01$, or $0.001 \mathrm{M} \mathrm{NAG}$; and culture filtrates of $B$. cinerea, $R$. solani, or $P$. ultimum obtained by filtering $(0.22 \mu \mathrm{m})$ cultures of the phytopathogens grown in PDB at $25^{\circ} \mathrm{C}$ for 10 days. Total RNA was extracted by using the TRI Reagent buffer (Sigma-Aldrich), separated electrophoretically on a $0.8 \%$ formaldehyde-agarose gel, and transferred onto Hybond $\mathrm{N}^{+}$nylon membrane (Amersham Bioscience). Northern analysis was performed by using the DIGlabeled 393-bp Taabc 2 probe and membrane prehybridization, hybridization, and development protocols recommended by the DIG-labeling kit (Roche). mRNA and cDNA for the RT-PCR analysis were prepared from total RNA by using the Genelute mRNA Miniprep kit (Sigma-Aldrich) and the AccuScript High Fidelity First Standard cDNA Synthesis Kit (Stratagene, La Jolla, CA, U.S.A.), respectively. Amplification was obtained by using the TABC2for 1 and TABC2rev1 (Table 1) specific primers designed on the partial sequence identified as a portion of an $\mathrm{ABC}$ transporter gene. Actin was used as a housekeeping gene and its cDNA was amplified with the TrAct1F and TrAct1R primers (Table 1). All gene expression data were confirmed by performing each experiment at least twice.

\section{Construction of the $T$. atroviride mutants.}

Targeted disruption of Taabc2 was obtained by using the construct $p \Delta T a b c 2$ (Fig. 1), which is based on pAN7-1 (Punt et al. 1987) and contains the $h p h$ cassette positioned between two portions of the T. atroviride gene. Four primers (SLABglII, SLBStuI, SLCXbaI, and SLDNarI) (Table 1) were used to amplify the two Taabc2 fragments (Fig. 1): a 962-bp fragment (SLA-SLB) of the promoter region in which BglII and StuI sites were introduced, and a 921-bp fragment (SLC-SLD) near the end of the gene in which XbaI and NarI sites were introduced (Fig. 1). The two fragments were ligated into pAN7-1 following BglII-StuI (SLA-SLB) and XbaI-NarI (SLC-SLD) digestion (Fig. 1). The resulting plasmid was transferred into T. atroviride P1 by a standard, polyethylene glycol-mediated, protoplast transformation procedure (Punt et al. 1987). The transformants were selected on PDA + hygromycin at $100 \mathrm{ppm}$ and subjected to three rounds of monospore selection as well as subculturing in the absence and again in the presence of the antibiotic, in order to ensure the homokaryotic stage. Stable transformation and homologous insertion, with the absence of intact copies of Taabc2, was confirmed by PCR by using the primer pair HPHrev/HPHforw (Table 1), and by Southern analysis with both the 393-bp Taabc2 fragment and the $h p h$ probe.

T. atroviride P1 GFP mutants were obtained by transforming the fungus with the construct pTaabc2::GFP obtained by ligating $914 \mathrm{bp}$ of the Taabc2 promoter region to the GFP 
gene:tchb2 terminator fragment that was released from the plasmid pZEGA3 (Zeilinger et al. 1999) with an XbaI-HindIIII cut. Mutants were characterized as described by Zeilinger and associates (1999) and used to test GFP expression in the presence of different carbon sources, toxins, and pathogen mycelia. In particular, the activation of Taabc 2 during the interaction with a living $R$. solani colony was tested in dual-culture assays following the method described by Zeilinger and associates (1999). The expression of the reporter gene was monitored both before and after the contact of the two confronting fungi (a Taabc2::gfp mutant and R. solani).

\section{Characterization of knock-out mutants.}

Antagonistic activity was tested on both PDA and SMS by a standard plate confrontation assay, in which the $T$. atroviride wild type and mutants were grown in the presence of $R$. solani, $B$. cinerea, or $P$. ultimum for at least 1 month. Resistance to pathogen toxins was determined by exposing P1wt and its mutants to culture filtrates of P1wt itself, B. cinerea, $R$. solani, or $P$. ultimum. Culture filtrates containing metabolite mixtures were obtained by growing each fungus in PDB at $25^{\circ} \mathrm{C}$ for 10 days in a rotary shaker $(150 \mathrm{rpm})$; then, the biomass was removed and the culture filtrate was filter sterilized and inoculated with $30 \mu \mathrm{l}$ of a $T$. atroviride (wild type or transformants) $1 \times 10^{8} / \mathrm{ml}$ conidia suspension. After 7 days of incubation, the T. atroviride biomass of each sample was collected, lyophilized, and weighed.

The wild-type and mutant strains were tested to determine the susceptibility to fungicides and various mycotoxins by growing the fungi in petri dishes containing agarized substrate: SMS (control), $\mathrm{SM}+1 \%$ fructose, $\mathrm{SM}+0.2 \%$ glucose, or $\mathrm{SM}$ $+0.5 \%$ chitin as the sole carbon sources; and SMS amended with the fungicides dicloran (1 to $10 \mathrm{ppm}$ ) or of various mycotoxins (aflatoxin B1, aflatoxin B2, aflatoxin G1, fusaproliferin, and beauvericin) at $5 \mathrm{ppm}$ provided by A. Ritieni (Department of Food Science, University of Naples "Federico II"). The mycotoxins were tested at a concentration $(5 \mathrm{ppm})$ that had no inhibitory effect on the growth of T. atroviride P1wt on SMS.

Mutant and wild-type biocontrol activity against the pathogens $R$. solani and P. ultimum were tested in vivo as described by Brunner and associates (2005) on tomato. Data presented are from at least three different experiments, with five replicates ( 15 seeds) for each treatment.

\section{ACKNOWLEDGMENTS}

This work was supported by the following projects: FIRB 2002 prot. RBNE01K2E7; PRIN 2003 prot. 2003070719-003, MIUR PON project no. DD12935 del 02/08/2002; MIURPON project no. DD1219 del 05/10/2004; MIUR PON project no. DD1801 del 31/12/2004; EU TRICHOEST QLK3-2002-02032; EU 2E-BCA2.

\section{LITERATURE CITED}

Abbas, A., McGuire, J. E., Crowley, D., Baysse, C., Dow, M., and O'Gara, F. 2004. The putative permease PhIE of Pseudomonas fluorescens F113 has a role in 2,4-diacetylphloroglucinol resistance and in general stress tolerance. Microbiology 150:2443-2450.

Andrade, A. C., Del Sorbo, G., Van Nistelrooy, J. G., and De Waard, M. A. 2000a. The ABC transporter AtrB from Aspergillus nidulans mediates resistance to all major classes of fungicides and some natural toxic compounds. Microbiology 146:1987-1997.

Andrade, A. C., Van Nistelrooy, J. G., Perry, R. B., Skatrud, D. L., and De Waard, M. A. 2000b. The role of ABC transporters from Aspergillus nidulans in protection against cytotoxic agents and in antibiotic production. Mol. Gen. Genet. 263:966-977.

Angermayr, K., Parson, W., Stoffler, G., and Haas, H. 1999. Expression of atrC - encoding a novel member of the ATP binding cassette transporter family in Aspergillus nidulans-is sensitive to cycloheximide. Biochim. Biophys. Acta. 1453:304-310.
Benítez, T., Rincón, A. M., Limón, M. C., and Codón, A. C. 2004. Biocontrol mechanisms of Trichoderma strains. Int. Microbiol. 7:249-260.

Brunner, K., Peterbauer, C. K., Mach, R. L., Lorito, M., Zeilinger, S., and Kubicek, C. P. 2003. The Nag1 N-acetylglucosaminidase of Trichoderma atroviride is essential for chitinase induction by chitin and of major relevance to biocontrol. Curr. Genet. 43:289-295.

Brunner, K., Zeilinger, S., Ciliento, R., Woo, S. L., Lorito, M., Kubicek, C. P., and Mach, R. L. 2005. Genetic improvement of a fungal biocontrol agent to enhance both antagonism and induction of plant systemic disease resistance. Appl. Environ. Microbiol. 71:3959-3965.

Callahan, T. M., Rose, M. S., Meade, M. J., Ehrenshaft, M., and Upchurch, R. G. 1999. CFP, the putative cercosporin transporter of Cercospora kikuchii, is required for wild type cercosporin production, resistance, and virulence on soybean. Mol. Plant-Microbe Interact. 10:901-910.

Chang, G. 2003. Multidrug resistance ABC transporters. FEBS (Fed. Eur. Biochem. Soc.) Lett. 555:102-105.

Chet, I. and Inbar, J. 1994. Biological control of fungal pathogens. Appl. Biochem. Biotechnol. 48:37-43.

Chet, I., Inbar, J., and Hadar, I. 1997. Fungal antagonists and mycoparasites. Pages 65-184 in: Environmental and Microbial Relationships. D. T. Wicklow and B. Söderström, eds. Springer-Verlag, Berlin.

Cortes, C., Gutierrez, A., Olmedo, V., Inbar, J., Chet, I., and HerreraEstrella, A. 1998. The expression of genes involved in parasitism by Trichoderma harzianum is triggered by a diffusible factor. Mol. Gen. Genet. 260:218-225.

Daniel, J. F., and Filho, E. R. 2007. Peptaibols of Trichoderma. Nat. Prod. Rep. 24:1128-1141.

Delgado-Jarana, J., Pintor-Toro, J. A., and Benítez, T. 2000. Overproduction of beta-1,6-glucanase in Trichoderma harzianum is controlled by extracellular acidic proteases and $\mathrm{pH}$. Biochim. Biophys. Acta 1481:289-296.

Delgado-Jarana, J., Rincón, A. M., and Benítez, T. 2002. Aspartyl protease from Trichoderma harzianum CECT 2413: Cloning and characterization. Microbiology. 148:1305-1315.

Del Sorbo, G., Andrade, A. C., Van Nistelrooy, J. G., Van Kan, J. A., Balzi, E., and De Waard, M. A. 1997. Multidrug resistance in Aspergillus nidulans involves novel ATP-binding cassette transporters. Mol. Gen. Genet. 254:417-426.

Del Sorbo, G., Schoonbeek, H.-J., and De Ward, M. A. 2000. Fungal transporters involved in efflux of natural toxic compounds and fungicides. Fungal Genet. Biol. 30:1-15.

Del Sorbo, G., Ruocco, M., Schoonbeek, H.-J., Scala, F., Pane, C., Vinale, F., and De Waard, M. A. 2008. Cloning and functional characterization of $B c a t r A$, a gene encoding an $\mathrm{ABC}$ transporter of the plant pathogenic fungus Botryotinia fuckeliana (Botrytis cinerea). Mycol. Res. 112:737-746.

De Waard, M. A., Andrade, A. C., Hayashi, K., Schoonbeek, H.-J., Stergiopoulos, I., and Zwiers, L. H. 2006. Impact of fungal drug transporters on fungicide sensitivity, multidrug resistance and virulence. Pest. Manage. Sci. 62:195-207.

Driessen, A. J., Rosen, B. P., and Konings, W. N. 2000. Diversity of transport mechanisms: Common structural principles. Trends Biochem. Sci. 25:397-401.

Fleissner, A., Sopalla, C., and Weltring, K. M. 2002. An ATP-binding cassette multidrug-resistance transporter is necessary for tolerance of $\mathrm{Gib}$ berella pulicaris to phytoalexins and virulence on potato tubers. Mol. Plant-Microbe. Interact. 15:102-108.

Harman, G. E., Howell, C. R., Viterbo, A., Chet, I., and Lorito, M. 2004a. Trichoderma species-opportunistic, avirulent plant symbionts. Nat. Rev. Microbiol. 2:43-56.

Harman, G. E., Lorito, M., and Lynch, J. M. 2004b. Uses of Trichoderma spp. to alleviate or remediate soil and water pollution. Adv. Appl. Microbiol. 56:313-330.

Howell, C. R. 2003. Mechanisms employed by Trichoderma species in the biological control of plant diseases: The history and evolution of current concepts. Plant Dis. 87:4-10.

Kratzer, C., Tobudic, S., Schmoll, M., Graninger, W., and Georgopoulos, A. 2006. In vitro activity and synergism of amphotericin B, azoles and cationic antimicrobials against the emerging pathogen Trichoderma spp. J. Antimicrob. Chemother. 58:1058-1061.

Lee, S. W., and Cooksey, D. A. 2000. Genes expressed in Pseudomonas putida during colonization of a plant-pathogenic fungus. Appl. Environ. Microbiol. 66:2764-2772.

Liu, Y., and Yang, Q. 2007. Cloning and heterologous expression of aspartic protease SA76 related to biocontrol in Trichoderma harzianum. FEMS (Fed. Eur. Microbiol. Soc.) Microbiol. Lett. 277:173-181.

Llama-Palacios, A., Lopez-Solanilla, E., and Rodriguez-Palenzuela, P. 2002. The ybiT gene of Erwinia chrysanthemi codes for a putative ABC transporter and is involved in competitiveness against endophytic bacteria during infection. Appl. Environ. Microbiol. 68:1624-1630.

Lorito, M., Peterbauer, C., Hayes, C. K., and Harman, G. E. 1994. Syner- 
gistic interaction between fungal cell wall degrading enzymes and different antifungal compounds enhances inhibition of spore germination. Microbiology 140:623-629.

Lorito, M., Mach, R. L., Sposato, P., Strauss, J., Peterbauer, C. K., and Kubicek, C. P. 1996a. Mycoparasitic interaction relieves binding of the Cre1 carbon catabolite repressor protein to promoter sequences of the ech42 (endochitinase-encoding) gene in Trichoderma harzianum. Proc. Natl. Acad. Sci. U.S.A. 93:14868-14872.

Lorito, M., Woo, S. L., D’Ambrosio, M., Harman, G. E., Hayes, C. K., Kubicek, C. P., and Scala, F. 1996b. Synergistic interaction between cell wall degrading enzymes and membrane affecting compounds. Mol. Plant-Microbe Interact. 9:206-213.

Lu, Z., Tombolini, R., Woo, S. L., Zeilinger, S., Lorito, M., and Jansson, J. K. 2004. In vivo study of Trichoderma-pathogen-plant interactions, using constitutive and inducible green fluorescent protein reporter systems. Appl. Environ. Microbiol. 70:3073-3081.

Mach, R. L., Peterbauer, C. K., Payer, K., Jaksits, S., Woo, S. L., Zeilinger, S., Kulling, C. M., Lorito, M., and Kubicek, C. P. 1999. Expression of two major chitinase genes of Trichoderma atroviride (T. harzianum $\mathrm{P} 1$ ) is triggered by different regulatory signals. Appl. Environ. Microbiol. 65:1858-1863.

Marra, R., Ambrosino, P., Carbone, V., Vinale, F., Woo, S. L., Ruocco, M. Ciliento, R., Lanzuise, S., Ferraioli, S., Soriente, I., Gigante, S., Turrà, D., Fogliano, V., Scala, F., and Lorito, M. 2006. Study of the three-way interaction between Trichoderma atroviride, plant and fungal pathogens by using a proteomic approach. Curr. Genet. 50:307-321.

Martins dos Santos, V. A. P., Heim, S., Moore, E. R. B., Strätz, M., and Timmis, K. N. 2004. Insights into the genomic basis of niche specificity of Pseudomonas putida KT2440. Environ. Microbiol. 6:1264-1286.

Mendoza-Mendoza, A., Pozo, M. J., Grzegorski, D., Martínez, P., García, J. M., Olmedo-Monfil, V., Cortés, C., Kenerley, C., and HerreraEstrella, A. 2003. Enhanced biocontrol activity of Trichoderma through inactivation of a mitogen-activated protein kinase. Proc. Natl. Acad. Sci. U.S.A. 100:15965-15970.

Nakaume, R., Hamamoto, H., Iada, J., and Akutsu, K. 2002. A novel ABC transporter gene, PMR5 is involved in multidrug resistance in the phytopathogenic fungus Penicillium digitatum. Mol. Genet. Genomics 267:179-185.

Omero, C., Dror, Y., and Freeman, A. 2004. Trichoderma spp. antagonism to the dermatophyte Trichophyton rubrum: Implications in treatment of onychomycosis. Mycopathologia 158:173-180.

Punt, P. J., Oliver, R. P., Dingemanse, M. A., Pouwels, P. H., and Van den Hondel, C. A. 1987. Transformation of Aspergillus based on the hygromycin B resistance marker from Escherichia coli. Gene 56:117-124.

Rey, M., Llobell, A., Monte, E., Scala, F., and Lorito, M. 2004. Trichoderma genomics. Pages 225-248 in: Fungal Genomics: Applied Mycology and Biotechnology, vol. 4. K. Arora and G. G. Khachatourians, eds. Elsevier, Amsterdam.

Rigot, J., and Matsumura, F. 2002. Assessment of the rhizosphere competency and pentachlorophenol-metabolizing activity of a pesticide-degrading strain of Trichoderma harzianum introduced into the root zone of corn seedlings. J. Environ. Sci. Health 37:201-210.

Rosado, I. V., Rey, M., Codón, A. C., Govantes, J., Moreno-Mateos, M. A. and Benítez, T. 2007 QID74 cell wall protein of Trichoderma harzianum is involved in cell protection and adherence to hydrophobic surfaces. Fungal Genet. Biol. 44:950-964.

Sambrook, J., Fritsch, E. F., and Maniatis, T. 1989. Molecular Cloning: A Laboratory Manual, 2nd ed. Cold Spring Harbor Laboratory Press, Cold Spring Harbor, NY, U.S.A.

Schirmbock, M., Lorito, M., Wang, Y., Hayes, C. K., Arisan-Atac, I., Scala, F., Harman, G. E., and Kubicek, C. P. 1994. Parallel formation and synergism of hydrolytic enzymes and peptaibol antibiotics, molecular mechanisms involved in the antagonistic action of Trichoderma harzianum against phytopathogenic fungi. Appl. Environ. Microbiol. 60:4364-4370.

Schnabel, G., Dait, Q., and Paradkar, M. R. 2003. Cloning and expression analysis of the ATP-binding cassette transporter gene $M F A B C 1$ and the alternative oxidase gene MfAOX 1 from Monilinia fructicola. Pest
Manage. Sci. 59:1143-1151.

Schoonbeek, H.-J., Raaijmakers, J. M. and De Waard, M. 2002. Fungal $\mathrm{ABC}$ transporters and microbial interactions in natural environments. Mol. Plant-Microbe Interact. 15:1165-1172.

Sharon, E., Bar-Eyal, I., Chet, I., Herrera-Estrella, A., Kleifeld, O., and Spiegel, Y. 2001. Biological control of the root-knot nematode Meloidogyne javanica by Trichoderma harzianum. Phytopathology 91:687693.

Sivasithamparam, K., and Ghisalberti, E. L. 1998. Secondary metabolism in Trichoderma and Gliocladium. Pages 139-191 in: Trichoderma and Gliocladium. C. P. Kubicek and G. E. Harman, eds. Taylor and Francis, London.

Stergiopoulos, I., Zwiers, L. H., and De Waard, M. A. 2003. The ABC transporter MgAtr4 is a virulence factor of Mycosphaerella graminicola that affects colonization of substomatal cavities in wheat leaves. Mol. Plant-Microbe Interact. 16:689-698.

Tronsmo, A. 1991. Biological and integrated controls of Botrytis cinerea on apple with Trichoderma harzianum. Biol. Control 1:59-62.

Urban, M., Bhargava, T., and Hamer, J. E. 1999. An ATP-driven efflux pump is a novel pathogenicity factor in rice blast disease. EMBO (Eur. Mol. Biol. Organ.) J. 18:512-521.

Vey, A., Hoagland, R. E., and Butt, T. M. 2001. Toxic metabolites of fungal biocontrol agents. Pages 311-346 in: Fungi as Biocontrol Agents: Progress, Problems and Potential. T. M. Butt, C. Jackson, and N. Magan, eds. CAB International, Bristol, U.K.

Vinale, F., Marra, R., Scala, F., Ghisalberti, E. L., Lorito, M., and Sivasithamparam, K. 2006. Major secondary metabolites produced by two commercial Trichoderma strains active against different phytopathogens. Lett. Appl. Microbiol. 43:143-148.

Viterbo, A., Ramot, O., Chemin, L., and Chet, I. 2002. Significance of lytic enzymes from Trichoderma spp. in the biocontrol of fungal plant pathogens. Antonie Leeuwenhoek 81:549-556.

Wilhite, S. E., Lumsden, R. D., and Straney, D. C. 2001. Peptide synthetase gene in Trichoderma virens. Appl. Environ. Microbiol. 67:50555062.

Woo, S. L., Donzelli, B., Scala, F., Mach, R., Harman, G. E., Kubicek, C. P., Del Sorbo, G., and Lorito, M. 1999. Disruption of the ech42 (endochitinase encoding) gene affects biocontrol activity in Trichoderma harzianum P1. Mol. Plant-Microbe Interact. 12:419-429.

Woo, S. L., Scala, F., Ruocco, M., and Lorito, M. 2006. The molecular biology of the interactions between Trichoderma spp., phytopathogenic fungi, and plants. Phytopathology 96:181-185.

Yedidia, I., Benhamou, N., and Chet, I. 1999. Induction of defense responses in cucumber plants (Cucumis sativus L.) by the biocontrol agent Trichoderma harzianum. Appl. Environ. Microbiol. 65:10611070

Yedidia, I., Benhamou, N., Kapulnik, Y., and Chet, I. 2000. Induction and accumulation of pathogenesis related protein activity during the early stages of root colonization by Trichoderma harzianum. Plant Physiol. Biochem. 38:863-873.

Yedidia, I., Shoresh, M., Kerem, Z., Benhamou, N., Kapulnik, Y., and Chet, I. 2003. Concomitant induction of systemic resistance to Pseudomonas syringae pv. lachrymans in cucumber by Trichoderma asperellum (T-203) and accumulation of phytoalexins. Appl. Environ. Microbiol. 69:7343-7353.

Zeilinger, S., Galhaup, C., Payer, K., Woo, S. L., Mach, R. L., Fekete, C., Lorito, M., and Kubicek, C. P. 1999. Chitinase gene expression during mycoparasitic interaction of Trichoderma harzianum with its host. Fungal Genet. Biol. 26:131-140.

\section{AUTHOR-RECOMMENDED INTERNET RESOURCES}

BioWorks, Inc. compatibility chart: www.bioworksinc.com/rootshield/pdf/techsheets/CompatibilityChart.pdf

National Center for Biotechnology Information BLASTX server: www.ncbi.nlm.nih.gov

TMHMM prediction server, v. 2.0: www.cbs.dtu.dk/services/TMHMM/ 